\title{
CONSERVATION ETHICS TODAY: ARE OUR CONSERVATION-RESTORATION THEORIES AND PRACTICE READY FOR THE TWENTY-FIRST CENTURY? INTRODUCTORY NOTES TO SOME CENTRAL ISSUES
}

\section{SCHÄDLER-SAUB Ursula ${ }^{1}$}

\footnotetext{
${ }^{1}$ Graduated in Conservation-Restoration, $\mathrm{PhD}$ in Art History, Speaker of the National Scientific Committee on Conservation-Restoration, ICOMOS Germany, Professor for History and Theory of Conservation-Restoration and Art History at the Faculty of Architecture, Engineering and Conservation, HAWK University of Applied Sciences and Arts in Hildesheim (Germany); ursula.schaedler-saub@hawk.de https://orcid.org/0000-0002-8072-8485
}

The present publication in the journal series "Protection of cultural heritage" of ICOMOS Poland and the Technical University of Lublin is the result of an interdisciplinary exchange and cooperation between three international and national scientific committees of ICOMOS (the ISC Theory and Philosophy of Conservation-Restoration, the ISC Stone, and the German NSC Conservation-Restoration of Wall Paintings and Architectural Surfaces), renowned institutions of conservation-restoration and history of art, as well as institutions of education and professional representation in this field (the National Italian Conservation Institute Opificio delle Pietre Dure OPD in Florence, the Kunsthistorisches Institut, Max-Planck-Institut in Florence, the European Confederation of Conservator-Restorers' Organisation E.C.C.O., the European Network of Conservation-Restoration Education ENCoRE, the Italian and German Professional Associations of Conservator-Restorers (A.R.I. Associazione Restauratori d'Italia and $V D R$ Verband der Restauratoren). It is based on an international ICOMOS conference held in Florence in March 2018, supported by the Fondazione Romualdo Del Bianco and its international institute Life Beyond Tourism.

The topics of the publication are focussed on the relationships between theory and practice of conservation-restoration in the field of heritage preservation, considering the positions and developments of the twentieth century for the challenges of the twenty-first century. Particular attention is directed to architectural heritage, its surroundings and its fittings, such as architectural surfaces and wall paintings, stuccos, decorative elements in stone, majolica, ceramic, etc. Due to the involvement of the initiative in the European Year of Cultural Heritage (EYCH) 2018, the contributions in this publication deal with experiences and perspectives of conservationrestoration especially in European heritage preservation-including a critical look from outside Europe-to provide important input and fresh perspectives. Students and young professionals 
active in the field of heritage preservation are represented by short contributions in the appendix of this publication.

The ethics of conservation concern issues of the relationship between objects and actors, i.e. between our heritage and the professionals dealing with heritage preservation. Ethical principles as a basis for developing appropriate methods and techniques of conservation-restoration are required. These applied ethics are closely connected with the professional ethics of conservatorrestorers and of all other specialists involved in the preservation of architectural heritage. One of the aims of this publication, with contributions from different points of view and different professional experiences, is to improve interdisciplinary understanding and cooperation between conservator-restorers, architects, craftsmen, art historians, building archaeologists, conservation scientists, and all others active in this field. With reference to everyday practice, the contributions deal with the specific professional profiles and tasks of all these specialists and try to increase the quality of communication and co-operation, with a close contact between theoretical positions and their significance for the practice of conservation-restoration.

A few notes can introduce the central topics of this publication:

Re-thinking conservation-restoration theories of the twentieth century in the early twenty-first century

The European tradition of heritage preservation, use and presentation is based on wellestablished theories of the twentieth century. The most famous and often quoted-maybe also sometimes misunderstood-theories are those of Alois Riegl, The Modern Cult of Monuments: Its Essence and Its Development, published in 1903 (Riegl, 1903), and of Cesare Brandi, Theory of Restoration, published in 1963 (Brandi, 1963; 1977), but written in the mid-twentieth century. ${ }^{1}$ For us, these theories are essential historical sources, the first one having been conceived as a commentary on a new Austrian law on the preservation of cultural heritage, the second one explicitly dedicated to the conservation-restoration of works of art, at that time mostly neglected in theoretical statements and traditionally handled with methods and techniques of craftsmanship and artistic re-interpretation. Both theories are philosophically founded, with precise definitions of complex terms and concepts, but also tied to the social context of their own time. Without any doubt, Riegl's broad and manifold definition of a cultural monument with its commemorative values and its present-day values is the most modern definition of the twentieth century, because it can embrace all material and immaterial expressions of human creativity and of human activities in general. For this reason, today Riegl's definition is even meaningful for specific conservation challenges unknown at that time, e. g. the conservation of modern and contemporary art in our day. But Brandi's theory, especially written for works

\footnotetext{
Brandi's Theory is based on his articles on the theory of restoration published from the late 1940s to the 1950s in the Bollettino dell' Istituto Centrale per il Restauro in Rome. These articles were published as a book for the first time in 1963; a first reprint with the Italian Carta del restauro in the appendix followed in 1977. The English translation of Brandi's theory of restoration was published in 2005, see: Brandi, 2005; the German commented translation (the only commented one in the series of translations promoted by Giuseppe Basile) was published in 2006, see: Brandi 2006.
} 
of art, can also be successfully applied today, e. g. in the preservation of built heritage. Both theories to this day offer extremely useful dialectic instruments for the development and evaluation of appropriate concepts for the conservation, mediation and use of cultural heritage. In Riegl's theory, it is the assessment between the commemorative values (age value, historical value, deliberate commemorative value) and the present-day values (use value, artistic value with the sub-categories newness value and relative artistic value) - and for today's demands of heritage preservation we can add without any problem some new values, e. g. current social values in the mediation and management of cultural heritage. In Brandi's theory, it is the stress between two antipodes, the historical instance on the one hand and the aesthetical instance on the other, and the challenge to keep them in an appropriate balance. This balance can bridge the gap between two apparently irreconcilable positions, i. e. between the mere conservation of the handed-down conditions and the aesthetic demands of a work of art, in its own time as well as at present. These aesthetic demands today can perhaps also be defined as requests of an appropriate presentation of cultural heritage from the point of view of the involved communities and stakeholders.

Dealing with Riegl's Modern Cult of Monuments, we must consider also the writings of another great figure in the field of heritage preservation at that time, Georg Dehio, and his debate with Riegl on theoretical positions and their practical influence on conservation-restoration. Dehio emphasized the monument as a historical document, with its handed-down materiality bearing witness not only to the original, but also to aging phenomena and human interventions collected in the course of time. In his pamphlet advocating for the preservation of Heidelberg Castle as a ruin, he recognized the historical and emotional values of such venerable archaeological evidence closely connected to its material substrate (Dehio, 1901). Based on this concept, he formulated his famous motto that the task of professionals and technicians active in this field is "to conserve, not to restore" (Dehio, 1905, p. 142). It's interesting to note that another prominent figure for the study and preservation of built heritage, Camillo Boito, in the late nineteenth century formulated this axiom in the cultural context of Northern Italy: "conservare non restaurare" (Boito, 1893). For Central Europe, this was a revolutionary concept against all trends of de-restoration and re-restoration so well established in the nineteenth century, and it's current until today, against the widespread tendencies to spruce up monuments in "new splendour", with painful losses to historical authenticity.

In 1978, Brandi's Theory of Restoration was readopted by Umberto Baldini with his Theory of Restoration and Methodological Unity ${ }^{2}$ (Baldini, 1978). Baldini did not enhance Brandi's sophisticated philosophical argumentation, but his great merit was a forceful development of reintegration methods and presentation concepts in the context of a convincing methodological system. He was able to implement such a system in close cooperation with the conservators of the Fortezza da Basso in Florence. With empathy for the aesthetic demands of fragmentary cultural heritage in general, Baldini did not restrict his thoughts to paintings and sculptures, but he also included their historical format and framework as well as their integration in an architectural context. Furthermore, he incorporated in his considerations the so-called minor

2 After the publication of 1978, a second volume with the same title followed in 1981; see: Baldini 1981. 
objects of arts and crafts. This broader definition of cultural heritage evolving from traditional perceptions of history of art, was an achievement of interdisciplinary cooperation, in the spirit of the European Year of Cultural Heritage 1975. Baldini's Methodological Unity is not frozen in time but developed further with a continuous critical evaluation of his re-integration methods in today's practice of conservation-restoration, with great results especially in Tuscany. ${ }^{3}$

Summing up, the classical conservation-restoration theories of the twentieth century have to this day preserved their currency in many concepts and criteria, and all in all they present a remarkable development potential. Core principles of today, such as interdisciplinary investigation and documentation, continuous maintenance and care, and preventive conservation, have their seeds in theory and methodology developed in the course of the twentieth century, sometimes even before. But what has changed in the last decades, what are the new theoretical challenges of the twenty-first century not considered by the theories of the last century? Step by step, we have abandoned the typical Eurocentric position in the perception and preservation of cultural heritage in favour of a broader view of diverse meanings and traditions of conservation-restoration in other parts of the world - with benefit also for the development of European theories and practice. Furthermore, today we recognize the necessity of a democratic participation in decision-making processes concerning concepts of conservation-restoration and their practical realisation, involving the communities historically and emotionally connected with their cultural heritage as well as the various stakeholders and users. In this way, the long-time exclusive debate between experts in the field of heritage preservation is becoming more and more open minded. Experts' knowledge still remains the fundament of sustainable decisions in conservation-restoration, but it must be explained to other groups of people with clear statements. Many important questions, e.g. the ethically and aesthetically appropriate presentation and mediation of cultural heritage, require respectful dialogue with all involved persons, as the basis for mutual decisions supported by experts and non-experts. In the last decades, various statements on theory and practice of conservation-restoration have emphasised the importance of inter- and transdisciplinary cooperation as the best practice for democratic decision-making processes in heritage preservation. As a representative example one could mention Salvador Muñoz Viñaz' Contemporary Theory of Conservation published in 2005 , with a comprehensive analysis of current challenges in conservation-restoration situated in a broader ethical and social context (Muñoz Viñaz, 2005).

\section{Meaning and practical relevance of international Charters, Principles and Documents}

Charters, Principles and Documents on heritage preservation enunciated and published by ICOMOS since the Venice Charter adopted in 1964 (The Venice Charter, 1964) have had an outstanding importance for the theory and practice of conservation-restoration to this day. After more than 50 years, the Venice Charter is now a historical document, from some points of

These results are essentially due to the experts of the OPD Opificio delle Pietre Dure e laboratori di restauro della Fortezza da Basso in Florence, and their theoretical research closely connected with a continuous implementation in exemplary conservation-restoration projects. 
view typical for the European needs of heritage preservation in the situation of rebuilding after World War II. But first, the Venice Charter is the foundation document of ICOMOS and the great prototype of all following ICOMOS Charters, with a strong ethical impact, thanks to its very clear structure and its accurate and short formulations, comparable with the wording of a law. For this reason, the definition of the term "restoration" in the Venice Charter is the most quoted definition of this term to this day (The Venice Charter, 1964, p. 48). This International Charter for the Conservation and Restoration of Monuments and Sites was mostly formed by architects, art historians and archaeologists active in the field of heritage preservation, but soon the charter was also appreciated by conservators active in other fields, e. g. in museums or libraries, and became the first doctrinal text for students starting their studies in conservation-restoration. How can we explain this extraordinary career of the Venice Charter? It is the concision and clarity of its definitions and statements - for many professionals and for young people they are better understandable and more useful in every day discussions than tricky theories. This can also explain the great social relevance of the Venice Charter, from the very first to this day. Even though the charter has no legal foundation, its moral commitment is recognized all over the world, with a remarkable influence on national legislation for the protection of monuments and sites.

In contrast to the Venice Charter, the Italian national charter on conservation-restoration, Carta del restauro, first edited in 1932 with reference to the Athens Charter of 1931, and revised several times, most recently in 1972 with reference to Cesare Brandi's Teoria del restauro, was drafted with the intent of legal validity, but unfortunately was never adopted by the responsible ministry of education (Brandi, 1977, pp.131-154). The Carta del restauro of 1972 circulated only in-house in the departments responsible for the preservation of monuments and sites and works of art. Its limited success was also caused by the very extensive appendix with partially time-bound methodical and technical recommendations on conservation-restoration. Thus, one can learn from this experience that charters must avoid too intricate formulations, because most people will not read them; furthermore, long-time accepted principles must avoid detailed instructions, because they rapidly become obsolete.

Returning to the international charters, documents and principles adopted by ICOMOS, one can remark that these mostly short doctrinal texts, compared to complex theoretical treatises, can respond adeptly to new demands of understanding, preservation, conservation-restoration and use of cultural heritage. In this way, many issues not given or not deepened enough at the time of the Venice Charter were presented in later documents dedicated to specific subjects, as an integration or updating of this charter.

As an example, one can quote the ICOMOS Principles for the Preservation and ConservationRestoration of Wall Paintings adopted in 2003 (ICOMOS Principles for the Preservation..., 2003). In the spirit of the Venice Charter, these principles emphasize issues such as the necessity

4 Note: in the Venice Charter, the terms conservation and restoration have the classical meaning in use until today e. g. in the Italian and German terminology. Restoration follows conservation, as a critical act of interpretation, with regard to the historical instance and the aesthetical instance and with the commitment to hand down a work of art to future generations. See: Brandi, 1963, quoted from: Brandi, 1977, chapter 1, p. 6. 
to preserve wall paintings in situ, as an integral part of the building or structure, with an appropriate site management, including preventive conservation and careful planning of access and use. Without going into technical details, the principles deal with core questions in the conservation-restoration of wall paintings, giving a guideline for owners, users and all experts involved. Thanks to the authority of ICOMOS, in difficult situations such a document can strengthen the position of conservators and boost scientific investigation and sustainable preservation.

By respecting and enhancing the Venice Charter, ICOMOS Charters and Documents were able to move away from Eurocentric positions, enriching classical principles with the introduction of new cultural, social and ethical concepts. Thus, the Burra Charter: the Australia ICOMOS Charter for Places of Cultural Significance, adopted for the first time in 1979 (The Burra Charter, 1979-2013), extends the term "historic site" to places of cultural significance. These places reflect the diversity of communities, including sites with natural and cultural features, with aesthetic, historic, scientific, social as well as spiritual values. In a more and more globalized world, the Nara Document on Authenticity adopted in $1994^{5}$ (The Nara Document, 1994) emphasizes the diversity of cultures and heritage as an irreplaceable source of spiritual and intellectual richness and demands an appropriate assessment of the values and authenticity of cultural properties within the cultural context to which they belong. To this day, this is a revolutionary farewell from normative ethics and standardized proceedings in the evaluation and preservation of cultural heritage all over the world. The respect of the specific social and spiritual values which connect a community to its cultural heritage, also implies recognising traditional methods of conservation, repair, maintenance and maybe renovation as part of these values. Traditional methods could contribute to the authenticity of cultural heritage, even though sometimes they may contradict well-established international principles and methods of conservationrestoration. Authenticity, this core term of modern conservation ethics, is not carved in stone but needs case-specific definitions, evaluating the tangible and intangible values of cultural heritage within specific cultural contexts, in an interdisciplinary and intercultural dialogue.

Thanks to these and other doctrinal texts, international attention since the 1990s has been thoroughly dedicated to long-neglected intangible values, with a concept of cultural heritage becoming more and more immaterial. ${ }^{6}$ This change of perspectives has also enriched the classical European discussion on the values of a monument, recognising that tangible and intangible values in most cases are the two sides of a single coin, closely connected together, and demanding the commitment to respect both values. From this it follows that the material conservation-restoration of the monument is not debatable but the Conditio sine qua non, i. e. the essential requirement to preserve its tangible and intangible values.

5 The Nara Document was drafted in Nara, Japan, in 1994, at the conference on Authenticity in Relation to the World Heritage Convention, organized by the Agency of Cultural Affairs of the Government of Japan in cooperation with UNESCO, ICCROM and ICOMOS.

6 Without deepen this concept, a reference to the UNESCO Intangible Cultural Heritage, see: https://ich.unesco.org/ 
Meaning and practical relevance of ethics and ethical guidelines in the conservation-restoration of heritage today

In everyday practice, the importance of conservation ethics is increasing. This phenomenon is closely connected to the establishment of conservation-restoration as a scientific discipline in the course of the twentieth century, with the goal to base the methods and techniques of intervention on philosophical, historical, and scientific foundations. What is the difference between ethics and theories of conservation-restoration? Are complex philosophical definitions and lines of arguments too far removed from the everyday needs of a rapidly changing society? Can applied ethics match better with the multi-layered social requirements and the operative practice of the professional world today? Indeed, since the 1990s, applied ethics and their subdisciplines have been the most expanding area of philosophy because they can give us easily understandable answers with practical relevance to pressing social and political problems, e. g. in the field of medicine, environment and generally in scientific research.

In the young academic discipline of conservation-restoration, applied ethics and professional ethics are closely connected together, with the goal to offer well-founded, comprehensive guidance in the manifold practical challenges of conservation-restoration. In view of these challenges, in the last decades conservator-restorers have become more and more involved in the interdisciplinary definition of core terms and core principles of heritage preservation. Often-used and sometimes misinterpreted terms and concepts have achieved more clarity, and some innovative or long-repressed principles have been able to receive their warranted attention. A core term and principle of modern conservation-restoration which reflects the preventive conservation already emphasized by John Ruskin in 1849 ("Take proper care of your monuments, and you will not need to restore them"; Ruskin 1849, chap. $6, \S 19$ ) was mostly neglected in the twentieth century. A further example of a core term and principle of conservation ethics with great impact for best practice in conservation-restoration is the socalled minimum intervention, combined with continuous monitoring and interdisciplinary evaluation of the preservation conditions of cultural heritage. Such a minimum intervention respects the historical authenticity of a monument and is closely connected with the chance of repeatable treatments e. g. of cleaning and consolidation in the course of time, instead of cherishing the illusion of reversibility, with the well-known drastic consequences. The list of core terms and principles of conservation-restoration is in continuous evolution, since it requires evaluation and updates based on interdisciplinary research about fundamentals, methods and techniques. This interdisciplinary research could decisively contribute to gaining more and more knowledge and awareness in the theory and practice of conservation-restoration.

Case studies in conservation-restoration have a great practical relevance for the definition and understanding of conservation ethics, too. With their wide variety of historical, aesthetic and ethic significance as well as their technical aspects, they are able to be a touchstone of theoretical fundaments, ethical principles and methods and techniques of conservation-restoration. What can we learn from historical case studies, how can we deal with their results today from various points of view (current state of preservation, problems of historical conservation techniques, aesthetic and social aspects, etc.), considering their historical values and their aesthetic 
message as well as social and scientific demands of today? Considering prominent European examples of conservation-restoration in the twentieth century, a central issue is how to deal with the fragment and the possibilities of re-integration from a historical and aesthetic point of view, including the needs of conservation. The evaluation of integration methodologies and techniques of the twentieth century may also rekindle a critical debate about virtual methods of re-integration and other perspectives offered by digital technologies.

Interdisciplinary cooperation and communication in the field of heritage preservation and management: professional ethics and tasks

The often-lamented gap between theory and practice in the twentieth century is also a result of a long-absent interdisciplinary dialogue especially between conservator-restorers on the one hand and art historians, architects and archaeologists on the other. Many case studies of conservation-restoration in the last century are evidence of the discrepancy between theoretical concepts mostly developed by art historians and architects active in the field of heritage preservation, and their implementation in practice by conservator-restorers, who often did not have an academic education but were skilled in their craft. The lack of mutual understanding probably was not even noticed by the involved persons, nor was the consequential contradiction of idea and outcome.

Considering the development of scientific conservation-restoration, the improvement of academic education for conservator-restorers, and the definition of the profession in the course of the twentieth century, and taking into account relevant contributions such as the ICOM-CC Code of Ethics (ICOM-CC Code of Ethics,1984), the Document of Pavia (The Document of Pavia,1997) and E.C.C.O. Professional Guidelines (E.C.C.O. Professional Guidelines 2002-2004), today we have optimum requirements to strengthen the professional position of conservator-restorers and their role in the interdisciplinary cooperation with other professionals dealing with the preservation of cultural heritage. Thus, we can accept and gradually resolve the everyday challenges, e. g.: How does cooperation run in the planning stage and on site, in theory and practice? How can we differentiate between the specific professional contributions of conservator-restorers and the activities of other professionals in the field of heritage preservation? How can we improve communication and interdisciplinary cooperation between all professionals involved? Several contributions in the present publication and the Resolution of Florence "Let's increase Interdisciplinary Cooperation in the Preservation of Cultural Heritage!" published in the annex, can offer practical proposals and answers to these and further questions.

Let us continue in this way to increase interdisciplinary and transdisciplinary communication and cooperation, thereby enlarging our knowledge about our cultural heritage and its sustainable conservation-restoration and use!

Acknowledgements: I thank Roger Skarsten, HAWK University of Applied Sciences and Arts in Hildesheim, Germany, for his kind proofreading! 


\section{Bibliography}

Baldini, U. (1978). Teoria del restauro e unità di metodologia. Firenze: Nardini editore.

Baldini, U. (1981). Teoria del restauro e unità di metodologia, volume secondo. Firenze: Nardini editore.

Boito, C. (1893). Questioni pratiche di belle art: restauri, concorsi, legislazioni, professione, insegnamento. Milano: Hoepli editore.

Brandi, C. (1963). Teoria del restauro: lezioni raccolte da L. Vlad. Borrelli, J. Raspi Serra, G. Urbani ... Con una bibliografia generale dell'autore. Roma: Edizioni di Storia e letteratura.

Brandi, C. (1977). Teoria del restauro. Torino: Giulio Einaudi Editore - Piccola Biblioteca Einaudi Ns.

Brandi, C. (2005). Theory of Restoration. Edited by Giuseppe Basile and the Istituto Centrale per il Restauro, translated by Cynthia Rockwell. With presentations by Giuliano Urbani, Nicholas StanleyPrice, Caterina Bon Valsassina, with texts by Giuseppe Basile, Paul Philippot, Giulio Carlo Argan, Cesare Brandi. Firenze: Nardini editore.

Brandi, C. (2006). Theorie der Restaurierung. Herausgegeben, aus dem Italienischen übersetzt und kommentiert von Ursula Schädler-Saub und Dörthe Jakobs. Mit einführenden Texten von Giuseppe Basile, Paolo D’Angelo und Ursula Schädler-Saub. Eine Publikation des Deutschen Nationalkomitees von ICOMOS in Kooperation mit dem Landesamt für Denkmalpflege im Regierungspräsidium Stuttgart, Baden-Württemberg, und dem Istituto Centrale per il Restauro. München: Verlag der Anton Siegl Fachbuchhandlung.

Dehio, G. (1901). Was wird aus dem Heidelberger Schloss werden? Quoted from: Huse, N. (1984, 3. Auflage 2006). Denkmalpflege. Deutsche Texte aus drei Jahrhunderten (pp. 108-115). München: Verlag C. H. Beck.

Dehio, G.(1905). Denkmalschutz und Denkmalpflege im neunzehnten Jahrhundert. Rede zur Feier des Geburtstages Sr. Majestät des Kaisers... Quoted from: Huse, N. (1984, 3. Auflage 2006). Denkmalpflege. Deutsche Texte aus drei Jahrhunderten (pp. 139-146). München: Verlag C. H. Beck.

E.C.C.O. (2002). E.C.C.O. Professional Guidelines (I) The Profession. E.C.C.O. Retrieved 20 December 2018 from http://www.ecco-eu.org/fileadmin/user_upload/ECCO_professional_guidelines_I.pdf

E.C.C.O. (2003). E.C.C.O. Professional Guidelines (II) Code of Ethics. E.C.C.O. Retrieved 20 December 2018 from http://www.ecco-eu.org/fileadmin/user_upload/ECCO_professional_guidelines_II.pdf

E.C.C.O. (2004). E.C.C.O. Professional Guidelines (III) Education. E.C.C.O. Retrieved 20 December 2018 from http://www.ecco-eu.org/fileadmin/user_upload/ECCO_professional_guidelines_III.pdf

ICOMOS Principles for the Preservation and Conservation/Restoration of Wall Paintings (2003). In: MONUMENTA I, Internationale Grundsätze und Richtlinien der Denkmalpflege/Principes et directives internationaux pour la conservation/International Principles and Guidelines of Conservation ( $\mathrm{pp}$. 188-197), herausgegeben von/édités par/edited by ICOMOS Deutschland, ICOMOS Luxemburg, ICOMOS Österreich, ICOMOS Schweiz (2012). Stuttgart: Fraunhofer IRB Verlag. 
Muñoz Viñaz, S. (2005): Contemporary Theory of Conservation. Oxford: Elsevier ButterworthHeinemann.

Riegl, A. (1903). Der moderne Denkmalskultus, sein Wesen und seine Entstehung. In: Riegl, A. (1995). Gesammelte Aufsätze. Mit einem Nachwort zur Neuausgabe von Wolfgang Kemp, Berlin: Gebr. Mann Verlag, pp. 144-193.

Ruskin, J. (1849). The Seven Lamps of Architecture, London: Smith, Elder.

The Burra Charter: the Australia ICOMOS Charter for Places of Cultural Significance (1979-2013). Retrieved 20 December 2018, https://australia.icomos.org/wp-content/uploads/The-Burra-Charter2013-Adopted-31.10.2013.pdf

The Document of Pavia. Preservation of Cultural Heritage: towards a European Profile of the ConservatorRestorer (1997). Retrieved 20 December 2018 from: http://www.encore-edu.org/Pavia.html

The ICOM-CC Code of Ethics for Conservators. The Conservator-Restorer: a Definition of the Profession. Copenhagen 1984. Retrieved 20 December 2018 from: http://www.encore-edu.org/ICOM1984.html

The Nara Document on Authenticity. Drafted in Nara, Japan, with UNESCO, ICCROM and ICOMOS (1994). In: MONUMENTA I, Internationale Grundsätze und Richtlinien der Denkmalpflege/ Principes et directives internationaux pour la conservation/International Principles and Guidelines of Conservation, herausgegeben von/édités par/edited by ICOMOS Deutschland, ICOMOS Luxemburg, ICOMOS Österreich, ICOMOS Schweiz (2012). Stuttgart: Fraunhofer IRB Verlag, pp. 141-146.

The Venice Charter. International Charter for the Conservation and Restoration of Monuments and Sites (1964). In: MONUMENTA I, Internationale Grundsätze und Richtlinien der Denkmalpflege/ Principes et directives internationaux pour la conservation/International Principles and Guidelines of Conservation (pp. 47-52), herausgegeben von/édités par/edited by ICOMOS Deutschland, ICOMOS Luxemburg, ICOMOS Österreich, ICOMOS Schweiz (2012). Stuttgart: Fraunhofer IRB Verlag. 